\title{
PELATIHAN PEMANFAATAN MEDIA DIGITAL STORY TELLING DALAM PEMBELAJARAN BAHASA INGGRIS BAGI GURU SMP DI WILAYAH SUBANG
}

\author{
Sri Supiah Cahyati ${ }^{1}$, Aseptiana Parmawati $^{2}$, dan Nai Supartini Atmawidjaja ${ }^{3}$ \\ 1,2,3 IKIP Siliwangi \\ srisupiahcahyati02@gmail.com ${ }^{1}$, aseptianaparmawati@gmail.com², \\ nai.supartini99@gmail.com ${ }^{3}$
}

\begin{abstract}
ABSTRAK
Pemanfaatan media pembelajaran yang belum optimal, menjadi salah satu masalah yang dihadapi guru di wilayah Subang, terlebihnya di desa jalan Cagak. Dalam proses pembelajaran, media pembelajaran menjadi salah satu unsur penunjang keberhasilan suatu pembelajaran. Pengabdian masyarakat ini bertujuan untuk dapat mendampingi dan membekali para guru SMP melalui pelatihan peningkatkan pengetahuan dan keterampilan dalam melaksanakan kegiatan pembelajaran berbahasa Inggris, dengan memanfaatkan media dan sumber bahan ajar yang tersedia di internet, terutama dengan menggunakan media pembelajaran Digital Story Telling. Metode yang akan digunakan dalam pengabdian masyarakat ini adalah metode pendekatan masalah atau transfer IPTEK. Metode yang dilakukan oleh tim pelaksana PKM terhadap mitra sekolah yaitu melalui melalui proses survey dan interview yang dilakukan secara berkesinambungan sehingga dapat menganalisis, mendiskusikan, dan memberikan pendampingan secara langsung terkait media pembelajaran Bahasa Inggris. Melalui kegiatan PKM ini, dapat disimpulkan bahwa para guru SMP di wilayah Subang memberikan respon yang positif dan sangat antusias sekali selama pelaksanakan pelatihan berlangsung. Dari pelaksanaan program PKM ini dapat disimpulkan bahwa pemanfaatan Media Digital Story Telling sangat diminati oleh para guru karena dapat dengan mudah diaplikasikan di kelas dalam proses pembelajaran Bahasa Inggris.
\end{abstract}

Kata Kunci : pelatihan 1, SMP 2, Digital Story Telling 3

\begin{abstract}
Utilization of instructional media that is not optimal has become one of the problems faced by some teachers at desa jalan Cagak, Subang. In the learning process, learning media is one of the supporting elements of the success of learning. The aim of this activity is to equip junior high school teachers through training and practicing, to improve knowledge and skills in carrying out learning activities in English, by utilizing media and teaching material resources available on the internet, especially by using Digital Story Telling as learning media. The method used in this activity is problem approach or transfer of science and technology. The method used by the team for school partners is through a continuous survey and interview process so that they can analyze, discuss, and provide direct assistance in learning English. Through this PKM activity, it can be concluded that the teachers in Subang gave a positive response and were very enthusiastic during the training. Through this program, the use of Digital Story Telling Media is very attractive to teachers because it can be easily applied in the classroom in the English learning process.
\end{abstract}

Keywords: training 1, junior high school 2, digital story telling

\section{A. PENDAHULUAN}

Perkembangan infrastruktur jaringan dan internet saat ini telah merambah ke berbagai daerah. Semakin banyak daerah yang bisa menikmati kehadiran internet. Baik di kota maupun di desa, internet sudah bisa dinikmati melalui berbagai jaringan. Begitu 
banyak peranan dari kehadiran internet ini. Salah satu peranan yang cukup besar disumbangkan adalah internet dalam bidang pendidikan.

Kesadaran akan pentingnya pendidikan bahasa Inggris berimplikasi pada upaya untuk mempelajari dan menguasai bahasa tersebut. Masyarakat pun saling berlomba memperkenalkan bahasa Inggris sedini mungkin kepada anak-anaknya. Fenomena ini ditangkap dengan cepat oleh lembaga-lembaga pendidikan, khususnya yang bergerak di bidang pendidikan setingkat SMP. Hal ini menjadi tantangan bagi para pendidiknya, khususnya pengajar bahasa Inggris, untuk mengembangkan dan mengimplementasikan suatu metode pembelajaran yang efektif dan menyenangkan dalam pembelajaran bahasa Inggris. Pendidikan dan pembelajaran bahasa Inggris didasari suatu pemikiran bahwa belajar bahasa asing atau bahasa kedua akan lebih baik bila dimulai lebih awal Hammerby dalam Khairani ( 2011).

Beberapa pengabdian dengan jelas menunjukkan bahwa anak-anak dan orang dewasa mempelajari bahasa dengan cara yang berbeda dan bahkan dengan cara yang lebih cepat (Santrock dalam Tyaningsih, 2016). Pengetahuan yang dikonstruksi peserta didik merupakan hasil interpretasi yang bersangkutan terhadap peristiwa atau informasi yang diterimanya, (Yazdi, 2012). Melalui media digital storytelling efek visual yang diberikan dapat berupa penggunaan warna yang beragam, katagori visual dan kata serta pembendaharaan visual dan kata yang beragam, sehingga memotivasi anak-anak dalam belajar (Yuliansyah dan Triyadi, 2018). Menurut Azis dan Majid dalam Karyadi (2018), Storytelling adalah seni bercerita yang lebih tinggi dan memerlukan banyak berlatih sebagai salah satu kegiatan seni bercerita, selain itu storytelling dapat menumbuhkan motivasi untuk menyimak cerita atau bercerita. Selaras dengan hal tersebut, Kusumaningrum, Arifin, dan Gunawan (2017) berpendapat bahwa metode ceramah yang dikombinasikan dengan gambar-gambar, animasi, dan display dapat memberikan materi yang relatif banyak secara padat, cepat, dan mudah.

Dari beberapa penjelasan tersebut, dapat disimpulkan bahwa media storytelling memiliki dampak yang positif dalam proses pembelajaran.

Subang merupakan wilayah yang memiliki infrastruktur jaringan dan internet yang sangat memadai. Namun hal ini masih kurang memotivasi para guru SMP atau sekolah yang sederajat untuk dapat memanfaatkan sumber daya yang ada dalam tiap pembelajaran, terutama dalam proses pembelajaran bahasa Inggris. Berdasarkan penjelasan tersebut, tim pelaksana kegiatan PKM merasa berkepentingan untuk 
membantu para guru agar dapat meningkatkan kualitas bahasa Inggris yang digunakan di dalam kelas melalui Pelatihan Pemanfaatan Media Digital Story Telling dalam Pembelajaran Bahasa Inggris bagi Guru SMP di Wilayah Subang".

\section{B. LANDASAN TEORI}

Tujuan pembelajaran dapat diraih melalui inovasi yang ada dengan menggunakan berbagai metode, pendekatan, sarana dan suasana yang mendukung dalam setiap prakteknya. Pemanfaatan internet untuk pendidikan, utamanya pembelajaran bahasa Inggris, sudah menjadi keharusan. Pemanfaatan teknologi informasi dan komunikasi dapat dilaksanakan dalam berbagai bentuk sesuai dengan fungsinya dalam pendidikan. Terlebihnya dalam pembelajaran Bahasa Inggris, yang dapat diwujudkan melalui pemanfaatan sumber pembelajaran dari internet dengan tidak meninggalkan 5 aspek, yang berupa : 1) kerangka konsep KTSP/KURTILAS, 2) silabus-RPP, 3) materi ajar, 4) media/alat peraga, dan 5) evaluasi pembelajaran.

Melalui pemanfaatan internet dalam e-learning diharapkan dapat menjadi media yang interktif, sehingga dapat menumbuhkan minat peserta didik, serta dapat merangsang daya pikir siswa untuk dapat menerima materi pembelajaran dengan baik. Hal ini tentu saja menjadi hal yang mendasar bagi para guru untuk dapat menguasai segala sesuatu media pembelajaran yang menggunakan internet dengan seksama.

Rusman (2011) berpendapat bahwa guru memegang peranan dalam proses pembelajaran, dimana proses pembelajaran merupakan inti dari proses pendidikan secara keseluruhan, oleh karena itu guru merupakan faktor penentu yang sangat dominan dalam pendidikan pada umumnya. Thoifuri dalam Rohmawati (2015) menyatakan bahwa pada prinsipnya guru adalah mereka yang mempunyai kompetensi keilmuan tertentu dan dapat dijadikan orang lain pandai dalam matra kognitif, afektif dan psikomotor, jadi seorang guru itu tidak hanya mereka yang memiliki kualifikasi keguruan secara formal diperoleh dari bangku sekolah perguruan tinggi.

Sebagian siswa lebih mudah memproses informasi belajar secara visual, sebagian lebih mudah memproses informasi melalui suara (auditorial), dan sebagian lain lebih mudah memproses informasi belajar dengan cara melakukan sentuhan (praktek) langsung atau kinestetik (Deporter \& Hernacki, 2011). 
Efektifitas belajar sangat dipengaruhi gaya belajar dan bagaimana cara belajar. Berikut ini adalah tabel efektifitas pembelajaran menurut (Bobbi \& Hernacki, 2011)

\begin{tabular}{lc}
\hline \multicolumn{1}{c}{ Informasi yang diperoleh } & Persentase \\
\hline Melalui membaca & $10 \%$ \\
Melalui mendengar & $20 \%$ \\
Melalui melihat & $30 \%$ \\
Melalui melihat dan mendengar & $50 \%$ \\
Melalui apa yang diucapkan & $70 \%$ \\
Melalui apa yang diucapkan dan & $90 \%$ \\
dilakukan & \\
\hline
\end{tabular}

Salah satu media pembelajaran yang dapat digunakan dalam proses pembelajaran adalah Digital Story Telling. Menurut Boltman dalam (Marfuaty \& Wahyudi, 2016) mendefinisikan Story telling sebagai sebuah dari sebuah keterampilan bernarasi dari cerita-cerita dalam bentuk syair atau prosa, yang dipertunjukkan oleh seseorang di hadapan audience secara langsung dimana cerita tersebut dapat disampaikan kembali dengan cara diceritakan atau dinyanyikan, baik dengan music atau tanpa music. Dapat juga melalui gambar ataupun dengan iringan lain yang mungkin dapat dipelajari secara lisan, baik melalui sumber cetak ataupun melalui sumber rekaman yang lainnya.

Berdasarkan penjelasan di atas, maka media digital storytelling dapat dimanfaatkan sebagai salah satu media kegiatan belajar yang dapat diaplikasikan dalam pembelajaran untuk meningkatkan kemampuan berbahasa Inggris untuk siswa setingkat SMP.

\section{METODE PELAKSANAAN}

Metode yang dipilih dalam melaksanakan kegiatan pengabdian masyarakat ini ini adalah pelatihan, diskusi, dan tanya jawab kepada para guru tingkat SMP di wilayah Subang. Langkah-langkah kegiatan yang ditempuh dilaksanakan dalam 4 tahap sebagai berikut:

1. Identifikasi permasalahan

Pada tahap ini tim pelaksana mengadakan observasi serta wawancara. Observasi dan wawancara ini dilaksanakan dengan berdiskusi dengan para guru yang ada di wilayah sasaran untuk memastikan persoalan yang dihadapi oleh para guru serta jumlah sekolah yang ada di lingkungan sekitar. 
2. Pengolahan informasi dan penentuan pemecahan masalah

Pada tahap ini tim pelaksana mengolah semua informasi baik berupa masukan hasil survei dan wawancara. Kajian teoretik dan empiris dikumpulkan terkait dengan usaha memberikan solusi terhadap masalah-masalah yang telah teridentifikasi. Adapun solusi yang segera perlu dilakukan adalah pemberian Pelatihan Pemanfaatan Media Digital Story Telling dalam Pembelajaran Bahasa Inggris bagi SMP di wilayah Subang sehingga melalui pelatihan ini diharapkan mampu meningkatkan kualitas bahasa Inggris para guru dalam proses pembelajaran.

\section{Penyusunan materi pelatihan}

Pada tahap ini tim pelaksana mulai menyusun materi berupa power point dan video digital story telling yang akan diberikan kepada para peserta pelatihan serta mencari referensi yang sesuai.

4. Kegiatan pelaksanaan

Pada tahap ini adalah kegiatan paling penting, yaitu pelaksanaan aplikasi dari Pelatihan Pemanfaatan Media Digital Story Telling dalam Pembelajaran Bahasa Inggris bagi Guru SMP di wilayah Subang. Kegiatan ini telah dilaksanakan di Balai Desa Jalan Cagak Subang dengan berbagai macam pertimbangan, salah satunya adalah keberadaan para guru yang merupakan alumni IKIP Siliwangi, sehingga memudahkan tim untuk melaksanakan kegiatan PKM, dengan pemerolehan informasi yang ada. Dalam kegiatan ini, tim pelaksana akan memberikan pelatihan dan penerangan materi serta mengadakan praktek langsung setelah pemberian materi diberikan.

\section{HASIL DAN PEMBAHASAN}

Pengabdian ini telah dilaksanakan pada tanggal 10 Agustus 2019 bertempat di Desa Jalan Cagak, Subang. Kegiatan ini dihadiri oleh para guru SMP di sekitar wilayah lokasi pengabdian masyarakat. Kegiatan ini kami bagi menjadi 4 sesi: 1) sesi pemberian materi, 2) sesi latihan, 3) sesi tanya jawab, 4) sesi interview. Adapun penjelasan dari setiap sesi adalah sebagai berikut:

1. Sesi pemberian materi

Pemberian materi dan latihan secara langsung kami aplikasikan dalam kegiatan tersebut. Kami juga membekali para peserta dengan modul terkait pembelajaran konvensional dan modern/ daring (story telling). Tujuan dari pemberian modul ini adalah supaya peserta dapat membandingkan sejauh mana keefektifan media story 
telling dibandingkan dengan media konvensional. Selama kegiatan berlangsung, kami dapati bahwa peserta sangat antusias terhadap materi yang diberikan.

2. Sesi latihan

Pada sesi kedua ini, kami memberikan kesempatan kepada peserta untuk dapat berlatih dalam mengaplikasikan media story telling. Kami membagi peserta menjadi 6 grup. Setiap grup berlatih untuk membuat media konvensional yang menarik, selain itu mereka juga berlatih untuk memilih judul cerita yang akan dicari di media youtube dimana cerita yang dipilih haruslah sesuai dengan tema pembelajaran yang ada, dan sesuai dengan skill yang telah dipilih. Dari sesi latihan ini, dapat kami simpulkan bahwa media daring lah yang lebih diminati oleh peserta.

3. Sesi tanya jawab

Dalam sesi ini, kami memberikan kesempatan kepada peserta untuk dapat bertanya langsung kepada kami terkait dengan materi pengabdian yang telah kami sampaikan hal ini bertujuan supaya para peserta benar-benar dapat mengerti, dan mampu mengaplikasikan media ini di kelas.

\section{Sesi interview}

Pada sesi terkahir, kami melaksanakan interview. Interview ini kami laksanakan pada 5 guru sebagai perwakilan dari seluruh peserta. Beberapa pertanyaan kami ajukan terkait dengan kegiatan pengabdian. Tujuan dari interview ini adalah untuk dapat mengetahui sejauh mana antusias peserta terhadap media pembelajaran yang telah disampaikan. Selain itu, melalui interview tim pengabdian dapat melakukan refleksi kegiatan dan dapat menjadi bahan acuan untuk dapat melaksanakan pengabdian yang selanjutnya lebih baik lagi.

Tabel 1. Pertanyaan Interview

1. Bagaimana pendapat anda terkait dengan kegiatan PKM hari ini?

2. Metode/Media mana yang lebih anda minati?

Daring/Konvensional?

3. Sudah pernahkah anda mengaplikasikan metode/media tersebut dalam proses pembelajaran Bahasa Inggris di kelas?

4. Kesulitan apa saja yang anda temui selama berlatih menggunakan media pembelajaran berupa Story Telling?

5. Perlukah kegiatan pelatihan seperti ini dilaksanakan secara berkesinambungan di setiap semesternya? 


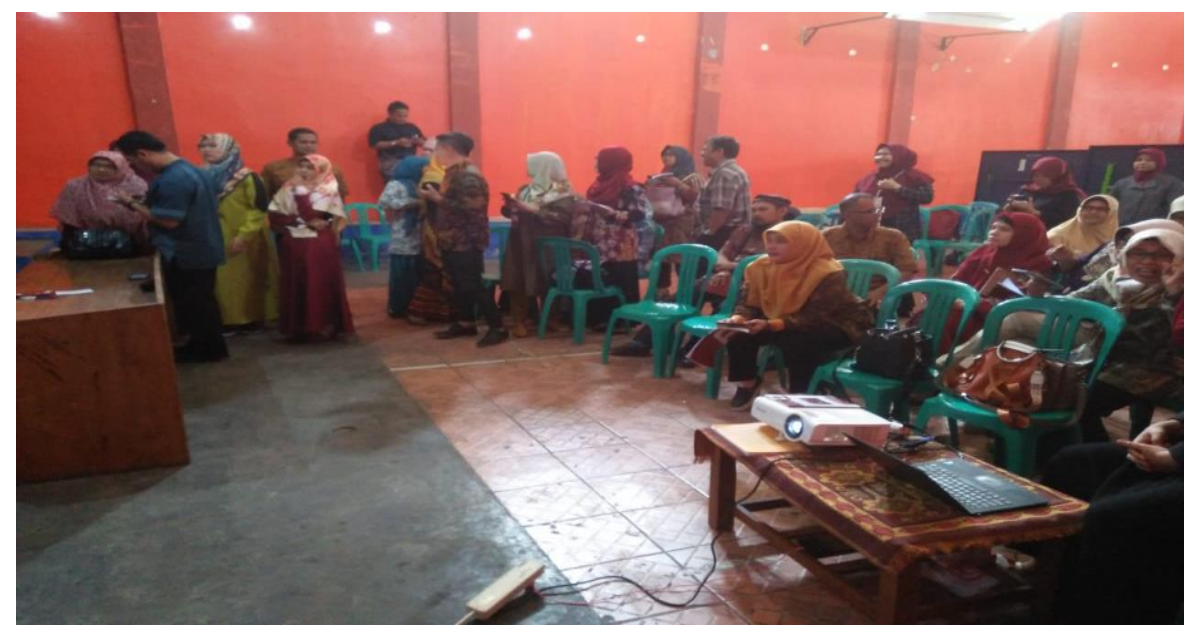

Gambar 1. Penggunaan Media Daring (Storytelling)

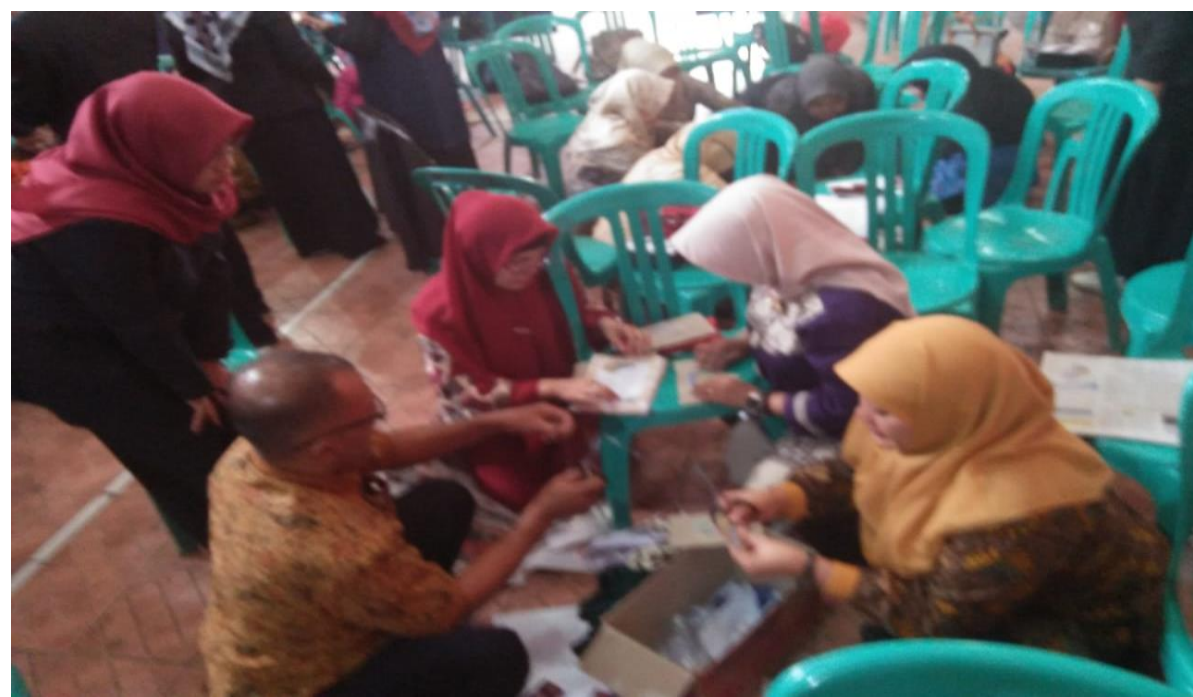

Gambar 2. Para Peserta Membuat Media Konvensional

\section{E. KESIMPULAN}

Berdasarkan data yang diperoleh dari kegiatan PKM, hasilnya menunjukkan bahwa:

1. Para guru mengakui bahwa mereka kurang memiliki pengetahuan tentang cara mengajar dengan menggunakan beberapa media pembelajaran secara Daring dalam pembelajaran Bahasa Inggris dikarenakan terbatasnya sosialisasi media pembelajaran yang diberikan untuk guru di sekitar wilayah desa Jalan Cagak pada khususnya.

2. Semua guru berpendapat keberadaan buku tutorial dalam penggunaan media pembelajaran secara Daring sangatlah diperlukan, hal ini bertujuan supaya para guru dapat lebih kompeten dan kreatif dalam mengelola kelas dengan memilih 
model, metode, teknik pembelajaran secara Daring yang tepat, serta mampu menentukan media pembelajaran yang sesuai dengan minat siswa.

\section{F. DAFTAR PUSTAKA}

Bobbi, D., \& Hernacki, M. (2011). Quantum learning. Jakarta: KAIFA.

Karyadi, A. C. (2018). Peningkatan Keterampilan Berbicara Melalui Metode Storytelling Menggunakan Media Big Book. Jurnal Pengabdian Masyarakat (Jpm-Ikp), 1(2).

Khairani, A. I. (2011). Pendidikan Bahasa Inggris Untuk Anak Usia Dini.

Kusumaningrum, D. E., Arifin, I., \& Gunawan, I. (2017). Pendampingan Pengembangan Perangkat Pembelajaran Berbasis Kurikulum 2013. ABDIMAS PEDAGOGI: Jurnal Ilmiah Pengabdian Kepada Masyarakat, 1(1).

Marfuaty, F. A., \& Wahyudi, R. (2015). An analysis of thematic progression patterns: Opinion section texts of The Jakarta Post, 9(3), 109-130.

Rohmawati, A. (2015). Efektivitas Pembelajaran. Jurnal Pendidikan Usia Dini, 9(1), 1532.

Rusman. (2011). Model-model pembelajaran: mengembangkan profesionalisme guru. Rajawali Pers/PT Raja Grafindo Persada.

Tyaningsih, A. R. (2016). Pembelajaran Bahasa Inggris pada Anak Usia Dini Berbasis Proses Pemerolehan Bahasa Pertama. JURNAL BARISTA, 3(1), 74-82.

Yazdi, M. (2012). E-learning Sebagai Media Pembelajaran Interaktif Berbasis Teknologi Informasi. In FORISTEK: Forum Teknik Elektro Dan Teknologi Informasi, 2(1).

Yuliansyah, H., \& Triyadi, A. (2018). Pengabdian Masyarakat Dalam Peningkatan Mutu Story Telling dan Visual di Rumah Pintar Bandung. Jurnal Abdimas BSI: Jurnal Pengabdian Kepada Masyarakat, 1(1). 